\title{
Zmiany stopy procentowej Narodowego Banku Polskiego w XXI w. na tle reguły Taylora
}

Changes in the interest rate of the National Bank of Poland in the 21st century against the Taylor rule

\section{Wprowadzenie}

Polityka pieniężna w XXI w. napotkała na bardzo burzliwe uwarunkowania. W pierwszej dekadzie wystąpił ogólnoświatowy kryzys finansowy i gospodarczy, w drugiej dekadzie deflacja i obecnie pandemia koronawirusa. Takie okoliczności sprawiają, że decydenci muszą prowadzić specyficzne, często niekonwencjonalne działania gospodarcze. Kształtowane przez wiele dziesiątek lat, w znacznym stopniu oparte na głównym nurcie ekonomii, status quo w polityce pieniężnej zostało zaburzone. Nadrzędny cel dotyczący stabilności cen często schodził na drugi plan, ustępując np. działaniom na rzecz wzrostu gospodarczego czy stabilności finansowej. Władze pieniężne musiały często sięgać po instrumenty niestandardowe. Krótkoterminowa stopa procentowa w obliczu napotkania na dolne ograniczenie stała się niewystarczającym narzędziem oddziaływania na gospodarkę, w szczególności w obliczu ujemnej dynamiki ogólnego poziomu cen.

Takie okoliczności sprawiły, że decydenci banków centralnych nie mogą prowadzić standardowych działań opartych na sztywnych zasadach i regułach. Ich decyzje i działania muszą być na bieżąco dostosowywane do zmiennych uwarunkowań i musi je cechować duży stopień dyskrecjonalności oraz elastyczności, a także ukierunkowanie na przyszłość. Nie oznacza to jednak, że współczesna polityka pieniężna ma być nieuporządkowana i nieklarowna. Wręcz przeciwnie, powinna być przejrzysta i wiarygodna, m.in. za sprawą zastosowania odpowiedniej strategii, w tym obecnie głównie bezpośredniego celu inflacyjnego. 
Taką strategię stosuje obecnie Narodowy Bank Polski (dalej: NBP), podejmując decyzje dotyczące zmian stóp procentowych w celu kontroli inflacji. Decydenci wykorzystują podejście wieloparametryczne, wspomagając się modelami ekonometrycznymi. Jakkolwiek decyzje podejmowane są na drodze głosowania członków Rady Polityki Pieniężnej (dalej: RPP) i są w dużym stopniu niezależne oraz dyskrecjonalne. Głównym celem tego opracowania jest analiza zmian stopy procentowej NBP w XXI w. Jako narzędzie badawcze wykorzystano regułę Taylora, która często stanowi odniesienie do zmian krótkookresowych stóp procentowych. W wielu przypadkach, mimo relatywnej swojej prostoty, dobrze opisuje faktyczne zmiany stóp procentowych w bankach centralnych. Należy jednak zadać pytanie, czy dopasowanie to miało zastosowanie w Polsce w kontekście burzliwych uwarunkowań gospodarczych w XXI w. Można postawić hipotezę, że współczesne, specyficzne uwarunkowania wymagają niestandardowej polityki pieniężnej. Standardowa polityka, oparta na regule Taylora, może nie być do nich adekwatna.

Opracowanie składa się z trzech głównych części. W pierwszej zarysowano współczesną politykę pieniężną, dokonując próby uchwycenia jej konsensu w zakresie celów, instrumentów i strategii. Ukazano przy tym rolę reguł i dyskrecjonalności w polityce pieniężnej. W drugiej części przedstawiono metodykę badania empirycznego zastosowanego w tym opracowaniu. Wskazano główne założenia badawcze oraz omówiono konstrukcję reguły Taylora. Trzecia część artykuł zawiera badania empiryczne, w których przeprowadzono analizę zmian stopy referencyjnej NBP w XXI w. na tle reguły Taylora. Dokonano przy tym oceny wybranych decyzji dotyczących zmiany tej stopy, w szczególności w latach 2015-2020.

\section{Reguła Taylora a współczesna polityka pieniężna}

Normatywne podejście do polityki gospodarczej każe ją analizować przez pryzmat trzech elementów: celów, instrumentów oraz ich powiązania zawartego w modelu. Wykorzystując takie podejście, można podjąć się próby uchwycenia pewnego konsensu w zakresie współczesnych doświadczeń polityki pieniężnej.

Jeśli chodzi o sferę celów, to mimo że literatura przedmiotu, a także historyczne doświadczenia wskazują na potencjalną ich wielość, w praktyce współczesnej polityki pieniężnej występuje duża zgodność. Stabilność cen jest często nadrzędnym, a nawet jedynym celem finalnym i strategicznym. Inne potencjalne cele, jak

1 Różne wielkości makroekonomiczne mogą być wykorzystywane w roli celów na trzech poziomach: operacyjnym, pośrednim i strategicznym (finalnym) (Przybylska-Kapuścińska, 2008, s. 22-28; Przybylska-Kapuścińska, 2002, s. 13). 
np. wspieranie wzrostu gospodarczego i zatrudnienia czy stabilność finansowa, uznawane są za drugorzędne. Mogą być realizowane w ramach polityki pieniężnej w takim zakresie, na ile nie szkodzi to celowi nadrzędnemu. Dodatkowo należy zaznaczyć, że cel dotyczący stabilności cen często jest zdefiniowany w sposób explicite. Wyraźnie określona jest jego wartość (najczęściej 2-3\%), horyzont (głównie średni okres) i sposób pomiaru (najczęściej CPI) (Błaszczyk, 2010a).

Pewien konsens można także zaobserwować, jeśli idzie o sferę instrumentów polityki pieniężnej. Mimo że w literaturze przedmiotu wyróżnia się wiele instrumentów, a przy tym różne ich klasyfikacje (Przybylska-Kapuścińska, 2008, s. 101-108), to obecnie głównym standardowym instrumentem polityki pieniężnej jest krótkoterminowa stopa procentowa, $\mathrm{z}$ uwzględnieniem różnych jej rodzajów. Mogą one dotyczyć operacji otwartego rynku (np. w Polsce stopa referencyjna) czy też operacji kredytowo-depozytowych (np. w Polsce stopa depozytowa i lombardowa).

Konsens wreszcie występuje w sferze strategii polityki pieniężnej, czyli sposobu powiązania celów z instrumentami. Ponownie potencjalnie można wskazać na różnorodność w tym zakresie (Błaszczyk, 2010b). Obecnie jednak w praktyce bankowości centralnej dominują strategie bezpośrednie, w tym w szczególności strategia bezpośredniego celu inflacyjnego. Rzadko natomiast są wykorzystywane strategie celów pośrednich, w tym kontrola podaży pieniądza.

Dzięki temu polityka pieniężna charakteryzuje się dużym stopniem dyskrecjonalności, która dodatkowo jest zwiększana przez niezależność banku centralnego. Przy podejmowaniu decyzji wykorzystywane jest podejście wieloparametryczne o charakterze forward looking (ukierunkowane na przyszłość). Proces decyzyjny wspierany jest poprzez różne, często zaawansowane modele ekonometryczne. Jednym $\mathrm{z}$ ich elementów jest funkcja reakcji, wskazująca na wartość stopy procentowej jako instrumentu polityki pieniężnej. Funkcja ta często przyjmuje postać reguły Taylora, a nawet nieraz jest nią nazywana. Nie zmienia to faktu, że sztywne reguły we współczesnej polityce pieniężnej nie są stosowane, a decyzje są w dużym stopniu dyskrecjonalne (Taylor, 2012).

Jakkolwiek reguła Taylora (1993, s. 195-214), mimo swojej relatywnej prostoty (porównując z modelami ekonometrycznymi) może być wykorzystywana jako narzędzie analityczne we współczesnej polityce pieniężnej (Taylor i Williams, 2011, s. 829-860), po pierwsze ze względu na to, że ma pewne zastosowanie w modelach ekonometrycznych, po drugie nawiązuje swoją konstrukcją do strategii bezpośredniego celu inflacyjnego, gdzie uwzględnia się przede wszystkim cel inflacyjny, a w dalszej kolejności inne cele, w tym dotyczące PKB, i po trzecie w wielu przypadkach szacunki reguły Taylora dobrze opisują faktyczne zmiany stóp procen- 
towych w ujęciu ex post (Taylor, 1998). Można jednak podać w wątpliwość, czy dopasowanie to miało zastosowanie w Polsce w kontekście burzliwych uwarunkowań gospodarczych w XXI w. W szczególności należy zadać pytanie, czy takie uwarunkowania wymagają niestandardowej polityki pieniężnej, a standardowa polityka, oparta na regule Taylora, może nie być do nich adekwatna (Gambacorta, Hofmann i Peersman, 2012; Hofmann i Bogdanova, 2012; Kendall i Ng, 2013).

\section{Metodyka badania}

Badanie empiryczne w tym opracowaniu polega na porównaniu szacunków reguły Taylora z faktyczną stopą procentową NBP. Na tej podstawie dokonano oceny wybranych decyzji RPP dotyczących ustalania stopy procentowej w ostatnich kilku latach, w szczególności w obliczu deflacji i dolnej granicy nominalnych stóp procentowych. W badaniu przyjęto kilka założeń:

- Cały zakres czasowy obejmuje XXI w., czyli początkowa cezura czasowa to 2001 r., a końcowa to początek 2020 r., jakkolwiek w analizie skupiono się głównie na kilku ostatnich latach.

- W ocenie porównawczej uwzględniono stopę referencyjną NBP.

- W badaniu wykorzystano regułę Taylora (1998, s. 9-11) o postaci:

$$
\mathrm{i}=\mathrm{r}^{*}+\Pi+\alpha\left(\Pi-\Pi^{*}\right)+(1-\alpha) \mathrm{y}
$$

gdzie:

i - szacunek stopy procentowej banku centralnego,

$\mathrm{r}^{\star}$ - realna stopa procentowa równowagi,

$\Pi$ - stopa inflacji,

$\Pi^{\star}$ - docelowa stopa inflacji,

$\mathrm{y}$ - luka produkcji,

$\alpha,(1-\alpha)-$ wagi.

- Dane o realnej stopie procentowej równowagi zostały oszacowane m.in. na podstawie własnych analiz polegających na testach różnych wartości w zakresie dopasowania szacunków reguły do danych rzeczywistych. Stopa ta przyjęła wartość maksymalną $8 \%$ dla początku okresu badawczego, a następnie spadała, by od 2010 r. przyjąć wartość 1\%.

- Lukę inflacyjną obliczono jako różnicę między rzeczywistą inflacją mierzoną CPI i wartością centralną celu inflacyjnego, czyli 2,5\%. Dynamikę cen na tle celu inflacyjnego zaprezentowano na wykresie 1. 
Wykres 1. Dynamika cen (CPI) w Polsce w XXI w. na tle celu inflacyjnego

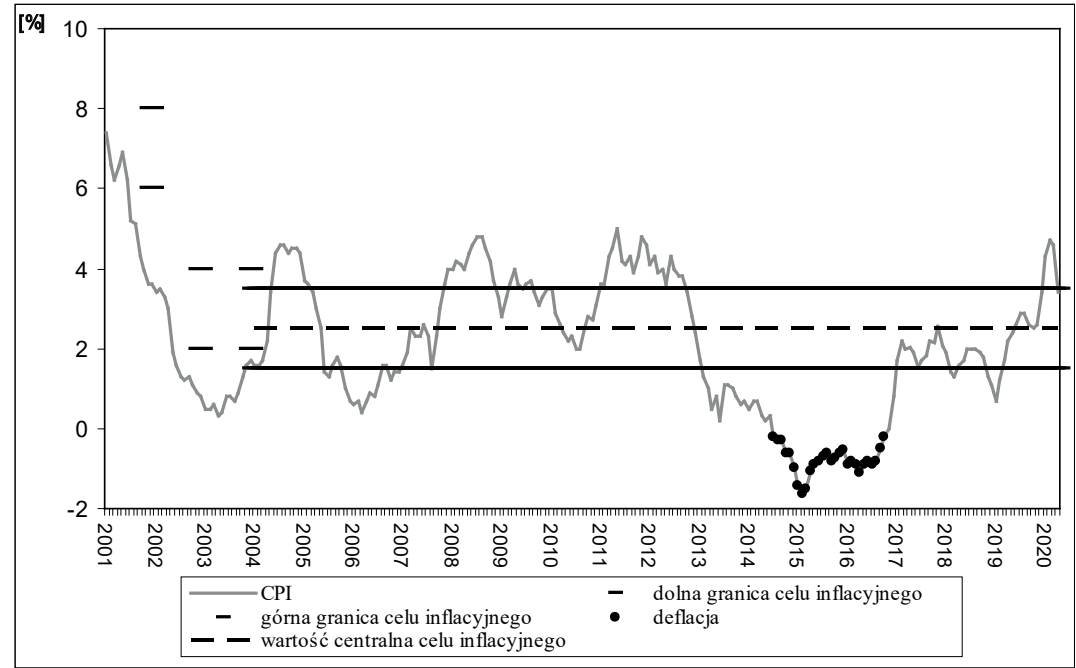

Źródło: opracowanie własne na podstawie danych GUS, NBP.

- Lukę produkcji wyznaczono przy pomocy filtru Hodricka-Prescotta. Ze względu na to, że dane o PKB dostępne są w ujęciu kwartalnym, przyjęto jednakową wartość dla miesięcy z tego samego kwartału. Wykorzystano dane oczyszczone sezonowo. Wartości luki produkcji przedstawiono na wykresie 2.

Wykres 2. Luka produkcji w Polsce w XXI w.



Źródło: opracowanie własne na podstawie danych Eurostat. 
- W regule uwzględnione zostały wagi przy lukach produkcji i inflacji. Ich układ mówi o relatywnym znaczeniu obu celów gospodarczych. Z istoty strategii bezpośredniego celu inflacyjnego, którą stosuje NBP, wynika, że waga przy luce inflacyjnej powinna być raczej większa ze względu na nadrzędność celu inflacyjnego. Im jest ona wyższa i dąży do jedności (w takiej sytuacji waga przy luce PKB dąży do zera), tym ma się do czynienia z mniej elastycznym wariantem strategii. Dla celów tego opracowania w kolejnym punkcie uwzględniono szacunki reguły Taylora $\mathrm{w}$ dwóch wariantach $\mathrm{z}$ wagami przy luce inflacji równymi 0,5 oraz 0,75 [oznaczono je odpowiednio jako $\mathrm{RT}(0,5)$ i RT $(0,75)$ ], czyli odpowiednio w sytuacjach gdy: równorzędnie traktowane są oba cele oraz cel inflacyjny jest nadrzędny, ale nie jedyny.

\section{Szacunki reguty Taylora dla Polski w XXI w.}

Na podstawie wykresu 3 w pierwszej kolejności można sformułować kilka wniosków ogólnych dotyczących porównania stopy referencyjnej z szacunkami reguły Taylora, które stanowią tło dla dalszych, bardziej szczegółowych analiz. Na rysunku można zaobserwować zbieżność stopy NBP i wynikającej z reguły Taylora, ale przede wszystkim do $2015 \mathrm{r}$. Dla tego okresu odnotowano wysoki współczynnik korelacji (prawie 0,9) oraz zbliżone wartości średnie obu szeregów.

Należy jednak zauważyć także pewne różnice dla tego podokresu, które wskazują na charakter prowadzonej przez NBP polityki. Po pierwsze należy dostrzec pewne opóźnienie, a po drugie - mniejszą zmienność stopy referencyjnej w stosunku do szacunków reguły Taylora. Może to świadczyć o tym, że władze pieniężne nie postępują nagle i pochopnie. Nie chcą zaskakiwać podmiotów sektora prywatnego zbyt częstymi i dużymi zmianami stopy procentowej. Czekają z decyzją na rozwój sytuacji gospodarczej, a w szczególności patrząc na jej wpływ na oczekiwania inflacyjne. Dążą do stabilizacji stopy procentowej, co jest zgodne z instytucjonalnymi uwarunkowaniami współczesnej polityki pieniężnej. Stabilizacja cen, w szczególności uwzględniając jej średniookresowy horyzont, nie musi wymagać zbyt nagłych i dużych zmian stóp procentowych zarówno w górę, jak i w dół, jeśli oczekiwania inflacyjne są zakorzenione, a działania banku centralnego wiarygodne, przejrzyste oraz odpowiednio rozłożone w czasie i ukierunkowane na przyszłość.

Kolejny ogólny wniosek, jaki można sformułować na podstawie wykresu 3, mówi, że dla całego okresu badawczego nieco większy współczynnik korelacji 
odnotowano dla wariantu RT(0,5). Może to świadczyć o tym, że w XXI w. dominowało bardziej luźne nastawienie w ramach strategii bezpośredniego celu inflacyjnego. Władze monetarne koncentrowały się nie tylko na celu inflacyjnym, ale i na celu drugorzędowym dotyczącym stabilnego wzrostu gospodarczego. Takie podejście jest zgodne z zaleceniami dotyczącymi realizacji strategii bezpośredniego celu inflacyjnego na etapie stabilizacji inflacji na niskim i optymalnym poziomie, już po zrealizowaniu etapu dezinflacji. W takich warunkach oczekiwania inflacyjne stają się zakorzenione i sprzyjają stabilizacji faktycznej dynamiki cen.

Wykres 3. Szacunki reguły Taylora i stopa referencyjna NBP w XXI w.

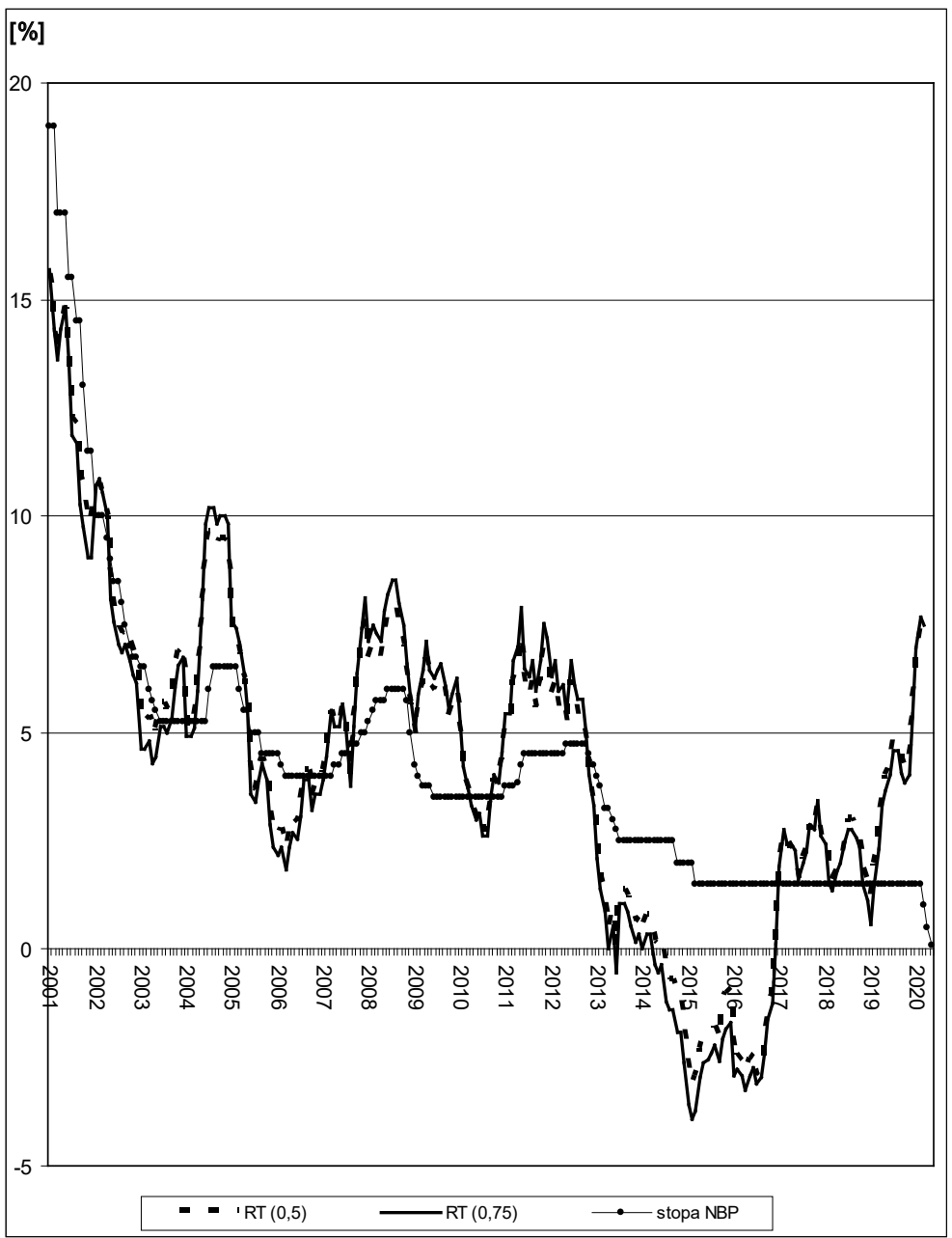

Źródło: opracowanie własne na podstawie danych Eurostat, GUS, NBP. 
Analizując natomiast kilka ostatnich lat na wykresie 3, widać, że zbieżność szeregów czasowych została zaburzona. Można zaobserwować największe odchylenia faktycznej stopy NBP od szacunków reguły Taylora zarówno w górę (głównie dla lat 2013-2016) oraz w dół (głównie dla 2019 r. i 2020 r.). W latach 2015-2020 korelacja zmieniła znak na ujemny. Jest to także widoczne w ujęciu realnym (wykres 4). Nagłe osłabienie dynamiki cen zapoczątkowane pod koniec 2012 r., a przede wszystkim deflacja trwająca nieprzerwanie od lipca 2014 r. do października $2016 \mathrm{r}$. wymusiły na RPP znaczną redukcję stopy referencyjnej z 4,75\% w październiku 2012 r. do 1,5\% w 2015 r. Przez kolejne 60 miesięcy decydenci NBP nie dokonali zmiany stopy procentowej, mimo że w latach 2014-2016 szacunki reguły Taylora wskazywały na potrzebę obniżenia jej poniżej zera, nawet w ujęciu realnym (wykres 4 ). W tym czasie ujemna nominalna stopa procentowa była stosowana przez niektóre banki centralne, jak np. Narodowy Bank Szwajcarii i Bank Japonii. Taką wstrzemięźliwość władz pieniężnych w Polsce można uzasadnić tym, że mieliśmy w tym czasie do czynienia z „dobrą" odmianą deflacji (Bordo, Lane i Redish, 2004) o charakterze podażowym i krótkotrwałym, powodowaną przez nagły i głęboki spadek cen ropy naftowej na rynkach światowych i innych surowców. Dopóty nie pojawiły się oczekiwania deflacyjne i mieliśmy do czynienia z dodatnią dynamiką PKB, dopóki decydenci NBP pozostawiali jeszcze pole manewru do obniżenia stóp procentowych w przyszłości, gdyby sytuacja gospodarcza miała się pogorszyć.

Wraz ze wzrostem cen ropy naftowej pod koniec 2016 r. deflacja w Polsce ustąpiła. Inflacja wróciła do docelowego pasma, a na początku 2020 r. nawet je przekroczyła. Można było się spodziewać podniesienia przez RPP stóp procentowych. Także reguła Taylora wskazuje na potrzebę ich podniesienia, przede wszystkim od początku 2019 r. (wykres 3). Tak się jednak nie stało i do marca 2020 r. stopy NBP pozostały bez zmian. Dopóki inflacja nie przekroczyła celu inflacyjnego, wstrzemięźliwość władz pieniężnych w Polsce nie była po raz kolejny zaskoczeniem, w szczególności mając na uwadze specyfikę procesu reflacji. Takie działania wpisywały się w ramy tzw. polityki minimalnej stopy procentowej (ang. minimum interest rates policy - MIRP), która jest skutecznym instrumentem antykryzysowym i antydeflacyjnym, o ile jest właściwie stosowana, tzn. stopy procentowe utrzymywane są na niskim, minimalnym (często zerowym, ale i ujemnym lub nieznacznie dodatnim) poziomie w dłuższym horyzoncie, także po ustąpieniu kryzysu i/lub deflacji - w warunkach reflacji (Okina i Shiratsuka, 2004; Ode i Ueda, 2007).

Najbardziej kontrowersyjna sytuacja pojawiła się jednak na początku $2020 \mathrm{r}$. Inflacja przekroczyła górną granicę docelowego pasma. W takich okolicznościach reguła Taylora wskazuje na potrzebę znacznego podniesienia stopy procentowej. 
Tymczasem RPP podjęła w marcu, kwietniu i maju trzy decyzje obniżające stopy procentowe, w tym ostatecznie stopę referencyjną do wartości $0,1 \%$. Stopa w ujęciu realnym, w obliczu wysokiej stopy inflacji, spadła znacznie poniżej zera. Jest to kolejny przykład prowadzenia przez NBP polityki o charakterze forward looking i w dużym stopniu dyskrecjonalnym (nieopartym na sztywnych regułach). Perspektywy załamania gospodarczego, w tym spadku PKB, w obliczu pandemii koronawirusa wywołały szybką i ukierunkowaną na przyszłość decyzję obniżenia stóp procentowych przez RPP. Ujemna realna stopa procentowa ma przyczyniać się do ożywienia gospodarki w najbliższych latach.

Wykres 4. Szacunki reguły Taylora i stopa referencyjna NBP w latach 2015-2020 w ujęciu realnym



Źródło: opracowanie własne na podstawie danych Eurostat, GUS, NBP. 
Z drugiej jednak strony należy mieć na uwadze, że decydenci NBP mogą mieć w przyszłości problem $\mathrm{z}$ dolną granicą nominalnych stóp procentowych ${ }^{2}$. Pole manewru do dalszej obniżki stóp jest znikome. Obecnie, przy pobudzonej inflacji i ujemnych realnych stopach procentowych, sztywność nominalnych stóp procentowych w dół nie stanowi problemu. Natomiast sytuacja znacznie pogorszyłaby się, gdyby wystąpiła deflacja, w szczególności w „złej” postaci, o charakterze popytowym. Wtedy nastąpiłby wzrost realnej stopy procentowej hamujący wzrost gospodarczy. Władze pieniężne utraciłyby swój główny instrument, jakim jest stopa procentowa. Konieczne byłoby wykorzystanie instrumentów niestandardowych.

\section{Zakończenie}

Polityka pieniężna w Polsce w XXI w. była prowadzona w burzliwych i zmiennych warunkach. Decydenci NBP musieli się zmierzyć m.in. w pierwszej dekadzie z ogólnoświatowym kryzysem finansowym i gospodarczym (por. Polański, 2017), w drugiej dekadzie ze zjawiskiem deflacji (Błaszczyk, 2019) i obecnie ze skutkami gospodarczymi pandemii koronawirusa. W tym kontekście konieczna była umiejętna polityka regulacji stopy procentowej zarówno w ujęciu nominalnym, jak i realnym.

Wymagające uwarunkowania sprawiły, że decyzje dotyczące zmiany stóp procentowych przez RPP były dokonywane w znacznym stopniu dyskrecjonalnie i z ukierunkowaniem na przyszłość. Mimo to przez pierwszych kilkanaście lat XXI w. występowała duża zbieżność faktycznej stopy referencyjnej NBP z szacunkami reguły Taylora. Zaobserwowano dużą dodatnią korelację obu stóp. Potwierdziła się teza, że reguła Taylora, mimo swojej prostoty i w obliczu po pierwsze - wykorzystania w praktyce bankowości centralnej złożonych modeli ekonometrycznych i po drugie - znacznego stopnia uznaniowości i dyskrecjonalności decyzji władz pieniężnych, dobrze opisuje faktyczne zmiany krótkoterminowej stopy procentowej jako głównego instrumentu polityki monetarnej.

2 Szerokie badania na temat zjawiska stóp procentowych bliskich zeru przeprowadza Rzońca (2014). Autor w kolejnych rozdziałach książki, wykorzystując nowy keynesowski schemat analityczny, przedstawia różne problemy i wyzwania wynikające z niskich stóp procentowych, odnosząc się m.in. do przykładów Japonii, Szwecji i Korei Południowej oraz dając wnioski dla współczesnej polityki pieniężnej, w tym w obliczu kryzysu pierwszej dekady XXI w. Por. także Rzońca (2004) oraz Bielecki, Brzoza-Brzezina i Kolasa (2018). 
Ostatnie lata przyniosły jednak załamanie zbieżności stopy referencyjnej NBP i szacunków reguły Taylora. Po pierwsze w obliczu deflacji RPP nie obniżyła stopy procentowej w takim stopniu, jak wskazywała reguła Taylora. Zalecana stopa powinna być ujemna w większości miesięcy, gdy występowała deflacja. Świadczy to o wystąpieniu usztywnienia stóp nominalnych w dól, mimo że nie były one zerowe. Sztywności stóp procentowych NBP uwidoczniły się także w ujęciu realnym. W obliczu deflacji i konieczności pobudzenia dynamiki cen pożądane byłoby obniżenie stopy realnej, w tym nawet do wartości ujemnych. Ujemną wartość realną stopy referencyjnej odnotowano dopiero w 2019 r., ale w obliczu rosnącej inflacji. W warunkach ujemnej dynamiki ogólnego poziomu cen realna stopa była zdecydowanie dodatnia, a w lutym 2015 r. najwyższa od marca 2006 r.

Wstrzemięźliwość decydentów NBP można wyjaśnić, przytaczając kilka argumentów. Po pierwsze należy zauważyć, że deflacja występująca w Polsce w latach 2014-2016 miała „dobry” charakter i nie było widocznych oznak jej transformacji w „złą” odmianę. Miała charakter przejściowy i wynikała przede wszystkim ze spadku cen ropy naftowej na rynkach światowych. Po drugie w tym czasie ogólna sytuacja makroekonomiczna w Polsce była dobra i decydenci zostawili sobie pewną barierę bezpieczeństwa, gdyby uległa ona pogorszeniu. Po trzecie wystąpiła pewna obawa przed obniżeniem stóp do zera lub nawet poniżej. W takiej sytuacji władze pozbyłyby się głównego narzędzia oddziaływania na gospodarkę, w tym przede wszystkim dynamikę cen.

Obniżenie stopy procentowej przez RPP do wartości bliskiej zeru nastąpiło dopiero w 2020 r. i to kontrowersyjnie w warunkach rosnącej inflacji. Przyczyną takiego działania są perspektywy załamania wzrostu gospodarczego w związku z pandemią koronawirusa. Władze pieniężne stoją obecnie w obliczu dylematu dolnej granicy nominalnych stóp procentowych. W przyszłości może pojawić się konieczność wykorzystania niestandardowych instrumentów (por. Przybylska-Kapuścińska, 2012; Wojtyna, 2001).

\section{Bibliografia}

Bielecki, M., Brzoza-Brzezina, M., Kolasa, M. (2018). Demographics, monetary policy, and the zero lower bound. NBP Working Paper, 284, 5-42.

Błaszczyk, P. (2010a). Stabilność cen - sposoby definicji oraz konsekwencje dla polityki pieniężnej. Materiały i Studia NBP, 249, 7-63.

Błaszczyk, P. (2010b). Systematyka współczesnych strategii polityki pieniężnej. Ruch Prawniczy, Ekonomiczny i Socjologiczny, 4, 131-150. 
Błaszczyk, P. (2019). Współczesna strategia polityki pieniężnej w warunkach deflacji. Perspektywa Unii Europejskiej w XXI w. Poznań: Wydawnictwo Uniwersytetu Ekonomicznego.

Bordo, M. D., Lane, J. L., Redish A. (2004). Good versus Bad Deflation: Lessons from the Gold Standard Area. NBER Working Paper, 10329, 1-50.

Gambacorta, L., Hofmann, B., Peersman, G. (2012). The effectiveness of unconventional monetary policy at the zero lower bound: a cross-country analysis. BIS Working Papers, 384, 1-30.

Hofmann, B., Bogdanova, B. (2012). Taylor rules and monetary policy: a global "Great Deviation"? BIS Quarterly Review, September, 37-49.

Kendall, R., Ng, T. (2013). Estimated Taylor Rules updated for the postcrisis period. Reserve Bank of New Zealand Analytical Note series, August, 2-23.

Polański, Z. (2017). Stabilization policies and structural developments: Poland and the crises of 1929 and 2008. CASE Working Papers, CASE 25th Anniversary Paper, 9(133), 9-86.

Przybylska-Kapuścińska, W. (red.). (2002). Polityka pieniężna. Cele, strategie i instrumenty. Poznań: Wydawnictwo AE.

Przybylska-Kapuścińska, W. (red.). (2008). Współczesna polityka pieniężna. Warszawa: Centrum Doradztwa i Informacji Difin.

Przybylska-Kapuścińska, W. (2012). Problemy polityki pieniężnej banków centralnych w okresie kryzysu. Ekonomia i Prawo, 3, 61-80.

Rzońca, A. (2004). Stopy procentowe banku centralnego bliskie zera a ryzyko wystąpienia deflacji, część I. Bank i Kredyt, 3, 22-30.

Rzońca, A. (2014). Kryzys banków centralnych. Skutki stopy procentowej bliskiej zera. Warszawa: C.H. Beck.

Taylor, J. (1993). Discretion versus policy rules in practice. Carnegie-Rochester Conference Series on Public Policy, 39, 195-214.

Taylor, J. (1998). An Historical Analysis of Monetary Policy Rules. NBER Working Paper, $6768,9-11$.

Taylor, J. (2012). Monetary policy rules work and discretion doesn't: a tale of two eras. The Journal of Money, Credit and Banking Lecture, March, 1017-1032.

Taylor, J., Williams, J. C. (2011). Simple and robust rules for monetary policy. W: B Friedman, M. Woodford (eds). Handbook of Monetary Economics. Elsevier (3B), 829-860.

Wojtyna, A. (2001). Skuteczność polityki pieniężnej w warunkach niskiej inflacji: problem zerowej granicy nominalnych stóp procentowych. Bank i Kredyt, 7, 4-17. 


\section{Streszczenie}

Głównym celem tego opracowania jest analiza zmian stopy procentowej NBP w XXI w. Jako narzędzie badawcze wykorzystano regułę Taylora, która często stanowi odniesienie do zmian krótkookresowych stóp procentowych. W wielu przypadkach, mimo relatywnej swojej prostoty, dobrze opisuje faktyczne zmiany stóp procentowych w bankach centralnych. Opracowanie składa się z trzech głównych części. W pierwszej zarysowano współczesną politykę pieniężną, dokonując próby uchwycenia jej konsensu w zakresie celów, instrumentów i strategii. Ukazano przy tym rolę reguł i dyskrecjonalności w polityce pieniężnej. W drugiej części przedstawiono metodykę badania empirycznego zastosowanego w tym opracowaniu. Wskazano główne założenia badawcze oraz omówiono konstrukcję reguły Taylora. Trzecia część artykuł zawiera badania empiryczne, w których przeprowadzono analizę zmian stopy referencyjnej NBP w XXI w. na tle reguły Taylora. Dokonano przy tym oceny wybranych decyzji dotyczących zmiany tej stopy, w szczególności w latach 2015-2020.

SŁoWA KLUCzowE: polityka pieniężna, reguła Taylora, stabilność cen.

\section{Summary}

The main purpose of the present study is to analyse changes in the interest rate of the National Bank of Poland in the 21st century. The Taylor rule, which often constitutes the reference to changes in short-term interest rates, was used as a research tool. In many cases, despite its relative simplicity, it describes well the actual changes in interest rates at central banks. The study consists of three main parts. The first outlines the contemporary monetary policy, attempting to capture its consensus in terms of goals, instruments and strategies. The role of rules and discretion in monetary policy was shown. The second part presents the methodology of the empirical research used in this paper. The main research assumptions were indicated and the construction of the Taylor's rule was discussed. The third part of the article contains empirical studies in which an analysis of changes in the reference rate of the National Bank of Poland in the 21st century was carried out against the background of the Taylor rule. Selected decisions regarding changes in this rate were assessed, in particular in the years 2015-2020.

KEYWORDS: monetary policy, the Taylor rule, price stability.

\section{Nota o autorze}

Paweł Błaszczyk - dr hab., Uniwersytet Ekonomiczny w Poznaniu, Katedra Koniunktury i Polityki Gospodarczej; główne obszary działalności naukowej: polityka pieniężna, integracja gospodarcza, uwarunkowania niskoinflacyjne i deflacyjne polityki gospodarczej; e-mail: pawel.blaszczyk@ue.poznan.pl; ORCID: 0000-0001-5104-1337. 